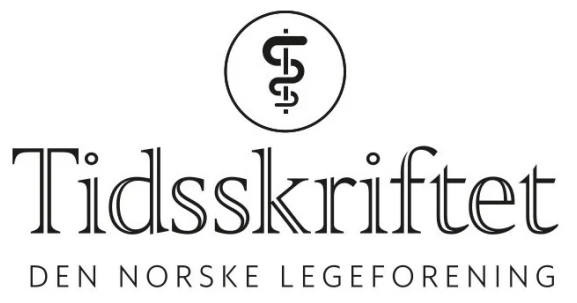

\title{
Deksametason kan trygt gis peroperativt
}

FRA ANDRE TIDSSKRIFTER

TORBJØRN ØYGARD SKODVIN

Tidsskriftet

Deksametason brukes mye peroperativt for å forebygge kvalme og oppkast. Det virker og har få bivirkninger, viser en stor randomisert studie. 


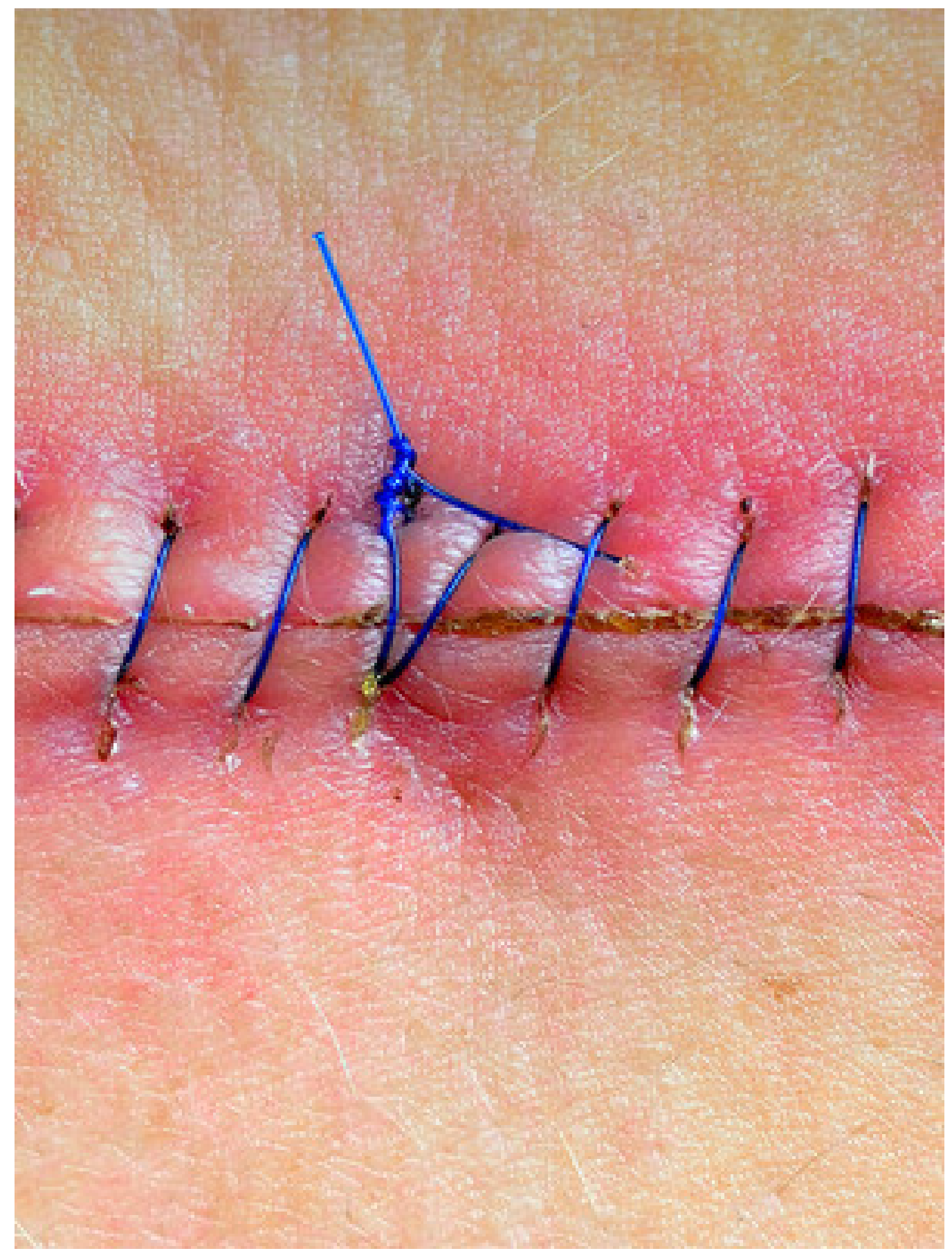

Foto: scholes1 / iStock

I forkant av større kirurgiske operasjoner gis ofte glukokortikoidet deksametason for å forhindre postoperativ kvalme og lindre smerte. Preparatet har imidlertid en potent immundempende virkning. Langvarig bruk gir dårligere sårtilheling og flere infeksjoner, men gjelder det også en enkelt peroperativ dose?

I en stor internasjonal multisenterstudie ble rundt 9 ooo pasienter randomisert til enten $8 \mathrm{mg}$ deksametason eller placebo mens de var i narkose for et større kirurgisk inngrep (1). Pasienter med dårlig kontrollert diabetes ble ekskludert. Nesten alle pasientene fikk profylaktisk antibiotikabehandling. I løpet av de neste zo dagene oppsto sårinfeksjon hos hhv. 8,1 og 9,1 \% i de to gruppene ( $\mathrm{p}<\mathrm{o}$,oo1 for ikke-underlegenhet). Det første døgnet fikk hhv. 42 og 54 \% kvalme og oppkast (risikoratio o,78; $95 \%$ KI o,75 til o,82). Hyperglykemi hos pasienter uten diabetes oppsto hos svært få, hhv. o,6 og 0,2\%.

- Denne studien viser at det er trygt å gi steroider peroperativt til pasienter med velregulert diabetes, sier Johan Ræder, som er overlege i anestesi og professor ved Oslo universitetssykehus. 
- Studien har mange pasienter, bekrefter tidligere mindre studie, og viser at deksametason har sikker profylaktisk kvalmedempende effekt ved et bredt utvalg av operasjoner, sier Ræder.

\section{LITTERATUR}

1. Corcoran TB, Myles PS, Forbes AB et al. Dexamethasone and surgical-site infection. N Engl J Med 2021;384: 1731-41. [PubMed][CrossRef]

Publisert: 12. august 2021. Tidsskr Nor Legeforen. DOI: 10.4045/tidsskr.21.0440

(C) Tidsskrift for Den norske legeforening 2023. Lastet ned fra tidsskriftet.no 26. april 2023. 